durante a sintese cirúrgica e complicações cicatriciais mesmo quando se optou pela "Sutura de Swain" ou "Walking Suture", conforme indica a literatura médica veterinária. Para minimizar as inconveniências como tensão exagerada nas linhas de sutura culminando com isquemia e deiscência, além do tempo prolongado de anestesia em pacientes que geralmente são geriátricos, optou-se pela técnica "Walking suture" modificada. O propósito deste trabalho é descrever os resultados obtidos com a técnica "Walking Suture" modificada empregada em cães, para a reconstituição de grandes defeitos de pele secundários às mastectomias. Foram efetuadas duas alterações na "walking suture", sendo que a primeira constou de substituição da sutura interrompida simples pelo padrão "Sultan". A segunda modificação feita foi a dupla inclusão das fáscias musculares reduzindo-se assim o tamanho da ferida a ser reconstituída. Com o padrão de sutura modificado, obteve-se redução de $38 \%$ no tempo médio de intervenção cirúrgica, fato importante, principalmente quando se trata de pacientes geriátricos, os quais são mais freqüentemente acometidos por afecções neoplásicas. Com as duas modificações propostas obteve-se redução do "espaço morto" e mobilização da pele para reduzir o defeito. Nos pacientes com grandes e múltiplos tumores envolvendo a região inguinal, constatou-se isquemia secundária as suturas empregadas sob tensão. Quando aplicouse "Walking Suture" em 26 animais, observou-se que em 08 pacientes $(30.7 \%)$ ocorreu deiscência parcial da sutura interrompida simples de pele, em aproximadamente $1 / 5 \mathrm{da}$ ferida, na região inguinal. Em 86 pacientes com as feridas reconstituídas com o padrão de sutura modificado, constatou-se o mesmo tipo de complicação cicatricial em 12 animais $(13,9 \%)$. Com esses resultados pode-se concluir que a técnica "Walking Suture" modificada é mais uma opção para a sintese cirúrgica de feridas com grandes perdas de pele, como ocorre após as extensas mastectomias.

Marcondes Santos, M'.; Chierichetti, A.L. ${ }^{2}$; Tonini, P. L. J. ${ }^{2}$; Fragata, F. S

\section{5 - Prolapso de uretra em cão da raça maltês. Relato de caso}

1- Departamento de Clínica Médica- Cardiologia do Hospital Veterinário Sena Madureira, São Paulo-SP

2- Departamento de Imagem- Ecodoppler do Hospital Veterinário Sena Madureira, São Paulo-SP

3- Departamento de Clínica Médica e Diretor de internaçăo do Hospital Veterinário Sena Madureira, São Paulo-SP

4- Departamento de Clínica Médica do Hospital Veterinário Sena Madureira, São Paulo-SP

O prolapso de uretra peniana é uma enfermidade rara. Na literatura é descrito acometendo cães jovens das raças braquiocefálicas. $\mathrm{O}$ prolapso pode ter como causa primária a irritaçào causada pela infecção gênito-urinária ou excitação sexual prolongada e os sintomas observados são a protrusão de uma massa na ponta do pênis e/ou sangramento peniano intermitente. O tratamento pode ser clínico mas na maioria das vezes o cirúrgico é o de escolha, podendo ser realizado tanto pela redução do prolapso como pela amputação do mesmo. $\mathrm{O}$ objetivo do relato é descrever esta enfermidade numa raça não comumente predisposta, bem como a técnica cirúrgica empregada e evolução pós-cirúrgica. Foi atendido no Hospital Veterinário Sena Madureira um cão da raça maltês, 4 anos de idade com quadro de sangramento intermitente em extremidade de pênis e há sete meses. $\mathrm{O}$ animal estava sendo medicado pelo proprietário com ketoprofeno sem melhora: Ao exame fisico constatou-se a presença de prolapso uretral e de sangramento. Foi realizada citologia (imprint), constatandose apenas tecido celular inflamatório. Não foram observadas alterações aos exames de ultrasonografia abdominal, hemograma, contagem de plaquetas e urinálise. Iniciou-se tratamento com predinisolona na dose de $0,5 \mathrm{mg} / \mathrm{Kg}$ a cada 24 horas observando-se a diminuição do sangramento, e solicitado tratamento cirúrgico. Optou-se pela técnica da amputaçào do prolapso para evitar recidiva do processo. Promoveu-se discreta tração do prolapso e colocando-se duas agulhas hipodérmicas atravessando a uretra de forma perpendicular, evitando a retraçào da uretra para dentro do pênis após sua incisão. Transercionou-se a uretra em toda a sua circunferência e, em seguida, esta foi suturada no pênis en pontos 
simples separados com fio de vicryl 5-0. Após término da amputação do prolapso foi realizada orquiectomia por técnica rotineira. No período pós-operatório o animal recebeu enrofloxacina na dose de $5 \mathrm{mg} / \mathrm{Kg}$ as cada 12 horas por 10 dias e predinisolona na dose de $1 \mathrm{mg} / \mathrm{Kg}$ a cada 24 horas durante cinco dias e mantido com colar elizabetano por 30 dias. Após 30 dias de pós operatório o animal encontrava-se em ótimo estado geral, não sendo mais observado sangramento.

\section{6 - Cirurgia de palato mole alongado em cães (estafilectomia)}

Leon Roman, M.A.';

Hofmann F. ${ }^{2}$; Gioso, M. A. ${ }^{3}$

\author{
1- Médico Veterinário autônomo - Odontovet, São Paulo-SP \\ 2- Médico Veterinário autônomo - Odontovet, São Paulo-SP \\ 3- Departamento de Cirurgia da Faculdade de Medicina Veterinária e Zootecnia da Universidade de São \\ Paulo, São Paulo-SP
}

Palato mole alongado em cães é um problema pouco diagnosticado na prática veterinária, podendo ocorrer em qualquer raça. Os sinais clínicos dependem do grau de estenose na faringe e incluem vômito, dificuldade de deglutição, ruídos respiratórios e, ocasionalmente, dispnéia. Casos severos podem incluir complicações maiores, como dispnéia, cianose, colapso de laringe e síncope, principalmente em braquicefálicos, por apresentarem anormalidades na estrutura nasolaríngea, assim como estreitamento das vias aéreas, edema dos tubérculos cuneiforme e corniculato da aritenóide, e eversão dos ventrículos laterais, aumentando assim, a resistência do ar na respiração. Durante a inspiração, a porção alongada do palato mole pode obstruir a laringe, interferindo na entrada de ar pela traquéia, resultando em processo inflamatório e edema na região, devido ao permanente contato entre as estruturas. Estes sinais acentuam-se principalmente durante o estresse, cansaço, no aumento da atividade física e em temperaturas elevadas. O diagnóstico é realizado através de exame físico, observando-se a relação entre o palato mole e o espaço existente na faringe, através de laringoscópio ou endoscopia. O palato mole deve apenas tocar a extremidade da epiglote ou se estender até a porção caudal ou média da tonsila, evidenciando a laringe. Entretanto, esta relação pode ser modificada quando não houver um correto posicionamento da cabeça $\mathrm{e}$ do pescoço, bem como da mandỉbula. A correção é realizada mediante procedimento cirúrgico, devendo o animal permanecer em decúbito esternal e a cavidade oral aberta a fim de melhor evidenciar o local de acesso. No trans-operatório faz-se necessário o uso de corticóides, na tentativa de minimizar o edema na região. Através de uma pinça de Allis, o alongamento do palato mole é forçado a voltar para sua posição normal. Em cada extremidade da porção alongada do palato é colocado um ponto de apoio para orientar a linha de incisão, que é realizada com uma lâmina de bisturi número 15 ou laser de alta potência. Para a sutura, utiliza-se fio absorvível à base de poliglactina 910 (Vicryl). Quando a ressecção ultrapassa o limite máximo, pode haver aspiração nasal de líquidos e alimentos, resultando em rinite e pneumonia. No período pós-operatório imediato, alguns sinais como vômito, ruídos respiratórios, e o engasgar são comuns. Durante as primeiras $24-48$ horas os reflexos faríngeos freqüentemente não funcionam normalmente $\mathrm{e}$ a aspiração ou obstrução nasal podem acontecer. Por isso, é importante identificar o problema cedo e instituir uma nova terapia imediatamente. De acordo com a literatura, pacientes com menos de 2 anos apresentam melhor prognóstico do que animais acima desta idade. Foi atendido no Laboratório de Odontologia Comparada , LOC-FMVZ/USP, um Poodle, 5 anos, fềmea, apresentando dificuldade respiratória, dispnéia, tosse e sons ruidosos na inspiração. O paciente foi submetido à anestesia geral inalatória, tendo sido pré-medicado com acepromazina $0,2 \%(0,1 \mathrm{mg} / \mathrm{kg})$, meperidina $(2 \mathrm{mg} / \mathrm{kg})$ e induzido com propofol $(5 \mathrm{mg} / \mathrm{kg})$, foi mantido em plano anestésico com isoflurano, para então realizar-se a estafilectomia. $\mathrm{O}$ animal apresentou boa recuperação pós-operatória e os sinais clínicos iniciais desapareceram por completo, e assim perduram há vários meses. 